\title{
A MAGYAR VADHÚSÉRTÉKESÍTÉS ALAKULÁSÁNAK FÖBB TENDENCIÁI ÉS LEHETSÉGES FEJLŐDÉSI IRÁNYAI
}

\author{
Komarek Levente - Tóth Szilvia
}

\begin{abstract}
Absztrakt: Magyarország kedvező természeti adottságokkal rendelkezik a vadgazdálkodás területén. Ebből kifolyólag lehetővé válik a vadászatra jogosultaknak, hogy kiváló alapanyagot (vadhúst) biztosítsanak a hazai és külföldi fogyasztók számára. A lőtt vad a vadfeldolgozókban történő gondos feldolgozást követően, jó minőségü, ellenőrzött termékként kerül a fogyasztók asztalára. A tanulmány az egyes lőtt nagyvadak (gímszarvas, dámszarvas, őz, muflon, vaddisznó) értékesítésének alakulására és lehetséges fejlődési irányaira fókuszál. A magyar vadhúsértékesítés az elmúlt évek során jelentős átalakuláson ment keresztül és ennek eredményeképpen szükségessé válnak olyan vizsgálatok, amelyek arra adnak választ, hogy milyen pozitív vagy negatív irányú változások következtek be ezen a téren. Az elemzéshez matematikai-statisztikai módszereket alkalmaztunk, annak érdekében, hogy be tudjuk mutatni a változások főbb tendenciáit, és meg tudjuk fogalmazni a főbb fejlesztési irányokat, figyelembe véve a magyar vadhús piacának erősségeit (S), gyengeségeit $(\mathrm{W})$, lehetőségeit (O) és veszélyeit $(\mathrm{T})$.
\end{abstract}

\begin{abstract}
Hungary has favourable natural resources considering the field of wildlife management. As a result, hunters can provide excellent raw material (game meat) for domestic and foreign consumers. The shot wild animals, after carefully processed in game-meat processing facilities, can be safely put on the consumers' table as good quality, controlled products. The study focuses on the sales and possible directions for the development of shot big game (red deer, fallow deer, roe-deer, mouflon, wild boar). Hungarian game sales have undergone a major transformation over the past few years, and as a result, tests are required to find out what kind of positive or negative changes have occurred in this field. We applied mathematical-statistical methods to analyse the main trends of change and to establish the main directions of development, regarding the strengths $(\mathrm{S})$, weaknesses $(\mathrm{W})$, opportunities $(\mathrm{O})$ and threats $(\mathrm{T})$ of the Hungarian game-meat market.
\end{abstract}

Kulcsszavak: vadhús, értékesítés, gímszarvas, dámszarvas, őz, muflon, vaddisznó

Keywords: game meat, sales, red deer, fallow deer, roe-deer, mouflon, wild board

\section{Bevezetés}

A Kárpát-medence klímája (három éghajlati terület határa) lehetővé teszi a gazdag, diverz flóra kialakulását, mely kiváló táplálékot nyújt a vadnak. A megfelelő minőségủ táplálék által alakulhat ki a jó beltartalmi értékekkel rendelkező vadhús. Magyarország természeti adottságaiból, valamint kedvező földrajzi helyzetéből adódóan képes arra, hogy Európában egyedülálló minőségű vadhúst állítson elő. A természeti adottságok bölcs hasznosítása a jól szervezett magyar vadgazdálkodás által valósulhat meg. Tehát a feltételek adottak egy megfelelő minőség és márka kialakításához belföldön és külföldön egyaránt (Abonyiné-Komarek, 2004; Horváth-Komarek, 2016; Komarek, 2004; Komarek, 2005; Komarek, 2008; SüliZakar-Komarek, 2012).

A hazai vadfeldolgozó cégek legtöbbje hosszú szakmai múltra tekint vissza, így rendelkeznek megfelelő tapasztalattal a piac adta igények kielégítéséhez. Ez egyértelmüen az erösségnek tekinthető. Erre a tapasztalatra szükség is van, hiszen a folyamatosan változó szabályozásokhoz történő alkalmazkodás, a szigorú 
követelmények betartása komoly kihívást jelent minden piaci szereplő számára (Berger-Csányi, 2015).

Az állategészségügyi előírások követése, azok alkalmazása a hús kiváló minőségének szelektálását, valamint megőrzését szolgálja, ám ezzel egy időben jelentős költségekkel terheli a vadfeldolgozókat (Balsay, 2013). A termelést tekintve azonban nem csak az állategészségügyi tesztek, valamint mikrobiológia minták költségeiről van szó, hanem alapanyagtól (féltest) függően a kihozatal arányáról is. Egy erösen szennyezett, roncsolt testből sokkal kisebb mennyiségü hasznos terméket lehet előállítani, mint egy megfelelő módon előkezeltből. A kobzást kezelni kell, az elszállítás és megsemmisítés szintén magas költségekkel jár. A nagy felvásárlási konkurencia miatt azonban nem minden cég alkalmaz osztályozási rendszert. Ebben az esetben kérdés, hogy mennyire lehet gazdaságosan termelni az egyébként is alacsony kihozatali arányok mellett? Megfontolandó egy egységes osztályozási rendszer kialakítása és alkalmazása a felvásárlási felületen. Ennek több előnye is lehet: a folyamatos verseny talán valamelyest gyengülne, mivel a felvásárlási árak az egységes osztályozási rendszer által korlátozottá válnának. Ez természetesen nem a szabad verseny megszüntetését jelenti, csupán a minőségi osztályozás meghatározását, azok ársávba való kivetítését. Amennyiben több I. osztályú vadhús kerül a feldolgozókhoz, csökken a veszteség, nagyobb a hozam. A vadászatra jogosultak nagyobb körültekintéssel ejtenék el és kezelnék a vadat, hiszen a megfelelő minőségü, tiszta testekért nagyobb bevételekre számíthatnának. Jelenleg a vadászatra jogosultak jelentősebb része elégedett a felvásárlási árakkal, de mindannyian szeretnének magasabb árat kapni a leadott hús után. Érthető, hogy a magasabb árért a felvásárlók viszont jobb minőséget igényelnek. Mivel a vadászatra jogosultak a lött vad közel 80\%-át értékesítik további kereskedőknek, vagy közvetlenül a vadfeldolgozóknak, így a bevétel növelése egyértelmüen a jobb minőség leadásában rejlik (Bíró, 2002; Gombos-Herényi, 2012).

A vadhús leadása során a vadászatra jogosultak előnyben részesítik a már ismert vadfelvásárlókat, akikkel az évek során sikerült jó üzleti kapcsolatot kialakítani. Az eladók többsége inkább preferálja azokat, akiket már ismernek és megbízhatónak tartanak, viszont akadnak országszerte olyan jogosultak is, akik a magasabb bevétel reményében nyitottak az új vadfelvásárlók felé. A probléma forrása abban rejlik, hogy ezek a cégek nem minden esetben megbízhatóak, adott időszakban jutányos árat tudnak ajánlani, de ez nem tartható hosszútávon, az ágazat hullámzó tendenciáit tekintve. Így fennáll a veszélye, hogy a jogosult elveszíti a korábbi, biztos felvásárlóját és a későbbiekben az új szereplő sem tud már megfelelő árat biztosítani. A hazai nagy felvásárlók igyekeznek azzal a megoldással biztosítani a saját helyzetüket, hogy hütőkamrákat telepítenek ki a beszállítók területére, ezáltal nyerve prioritást. A vadászatra jogosultak úgy vélik, a közeljövőben (1-2 éven belül) képesek lesznek növelni az értékesítésre szánt mennyiségét, annak ellenére, hogy véleményük szerint a hazai vadhúsfogyasztás nem fognak tartósan növekedni. Ennek okai föként a hazai életszínvonalra, ezáltal a magas értékesítési árakra vezethetők vissza. Az vadhús ÁFA-ja a korábbi kezdeményezések ellenére továbbra is $27 \%$, mely kedvezötlenül hat az egyébként is gyenge belföldi piacra. A magyar vadhús 
prémium kategóriás terméknek minősül külföldön. Hazai viszonylatban jelenleg szinte csak az olcsóbb kategóriába tartozó apró- és gulyáshúsok iránt van fizetőképes kereslet. Bár a hazai cégek mindegyike szeretné növelni a belföldi értékesítés arányát és „megszerettetni” a magyar emberekkel a vadhúst, a jelenlegi árak mellett a profitot hozó termelés csak külföldi értékesítéssel valósulhat meg. A hazai fogyasztás arányainak növelése egy hosszú folyamat, melynek a köztudatba egyre jobban rögzülni látszó egészségtudatos táplálkozás lehet az alapja, ez azonban NyugatEurópában már a hétköznapi élet részét képezi. Így napjainkban főként a profit tekintetében az exportpiacra kell a nagyobb hangsúlyt fektetni (Földvári, 2013; Földvári, 2014; Hajas, 2013; Kőhalmi-Márkus, 1996; Pechtol, 2016).

A vadhús feldolgozása során keletkezett termékek között is a fagyasztott áru van döntő többségben az előhütöttel szemben. Ugyanakkor elmondható, hogy a vadhús piaca szezonális változást mutat. Az előhütött, (általában vákuumcsomagolt) termékek iránti kereslet leginkább a föszezonban, azaz szeptembertől december végéig az előhütött termékekre van jelentős mennyiségü megrendelés, majd januártól augusztusig tart a „fagyasztási időszak”.

A magyar vadhús kiváló minősége világszerte elismert. Ezt az elismerést kell megbecsülni és lehetőség szerint a prémium kategóriás termékek előállítását növelni. A vad, mint megújuló energiaforrás bölcs hasznosítással, hosszútávon igen profitáló termékként lehet hazánk népszerü exportterméke (Laczay, 2008).

\section{Anyag és módszer}

Az elemzéshez adatforrásként a magyar Országos Vadgazdálkodási Adattár (OVA) által rendelkezésre álló statisztikai adatokat használtuk fel. Az adatokból olyan mutatókat képeztünk, amelyek lehetővé tették a magyar vadhúsértékesítés időbeni összehasonlító elemzését és a bekövetkezett változások föbb tendenciáinak bemutatását. Az elemzés a 2006 és 2016 közötti időszakot öleli fel.

$\mathrm{Az}$ elmúlt években a magyar vadhúsértékesítés esetében is jelentősebb változások következtek be. Ezek a változások szükségessé teszik olyan vizsgálatok elvégzését, amelyek válaszokat adnak arra vonatkozóan, hogy a magyar vadhúsértékesítés esetébe történtek-e pozitív vagy negatív irányú változások, illetve mely vadfaj súlya és szerepe növekedett vagy csökkent az elmúlt években ezen a téren. Ezen feltevések megválaszolására elemzésünkhöz matematikai-statisztikai módszereket alkalmaztunk.

\section{Eredmények és értékelésük}

A 2006 és 2016 közötti időszakban valamennyi vizsgált vadhús értékesítése növekvő tendenciát mutatott.

A lőtt nagyvadak közül a gímszarvas estében a bika, a tehén és a borjú értékesítésének alakulására fókuszáltunk. A bika értékesítése kisebb hullámzással, de növekedett a bázis évröl a tárgyévre. A növekedés 49,8\%-os volt (1. ábra). Hasonló növekvő tendencia jellemzi a tehén értékesítésének alakulását is. A tehén húsának értékesítése a 10 év során a tárgyévre a bázisévhez képest 91,9\%-kal 
növekedett (2. ábra). Jelentösebb növekedés tapasztalható a borjú húsának értékesítését illetően. A bázis évről a tárgyévre az értékesítés több mint duplájára emelkedett (3. ábra).

1. ábra: A magyar gímszarvas bika értékesítésének alakulása (2006-2016)

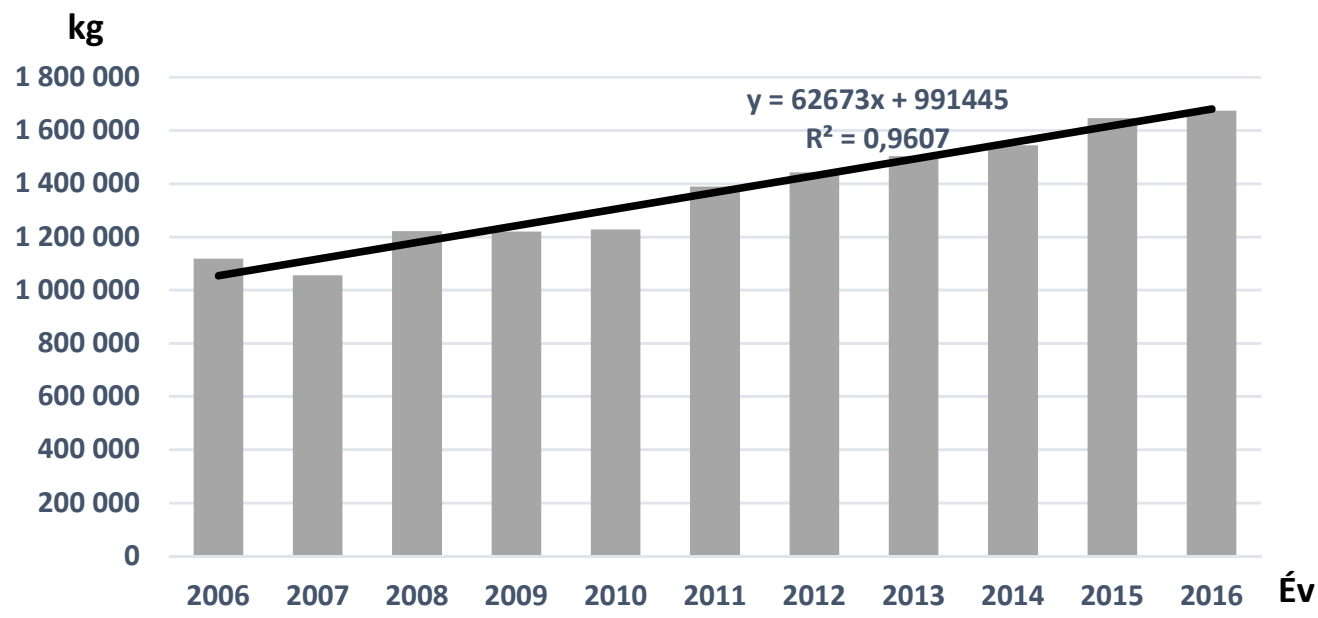

Forrás: OVA adatok alapján saját szerkesztés

2. ábra: A magyar gímszarvas tehén értékesítésének alakulása (2006-2016)

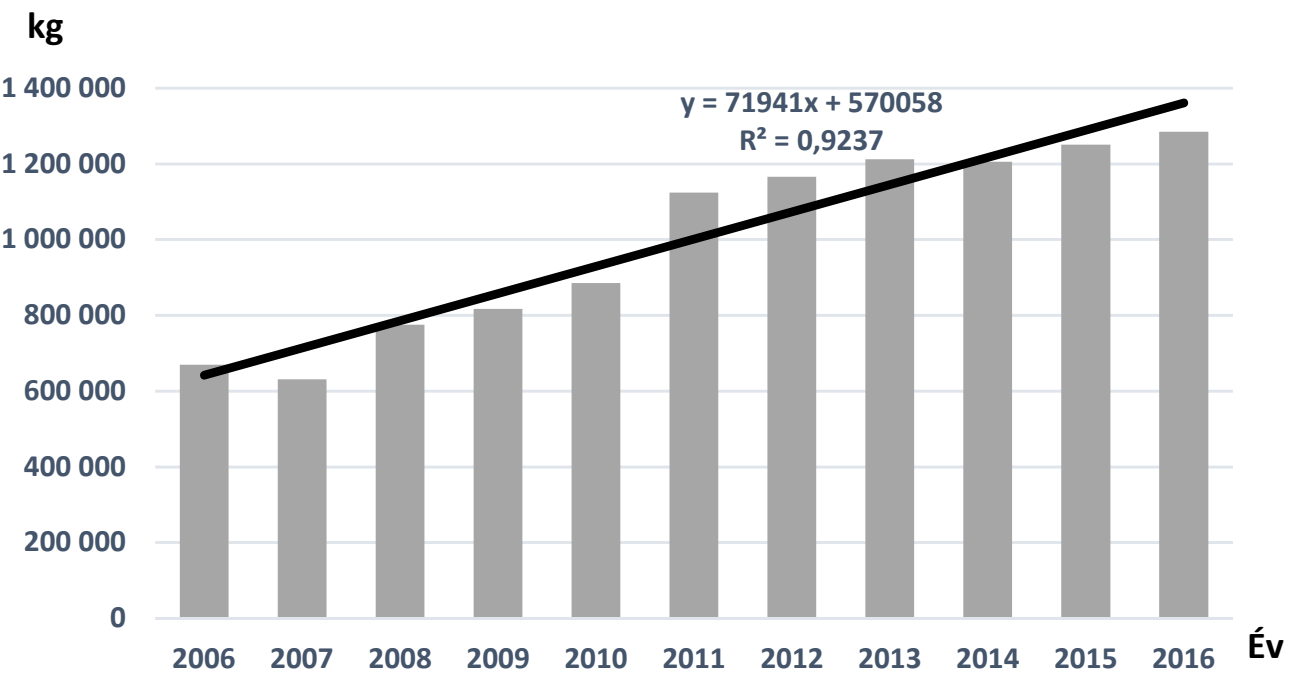

Forrás: OVA adatok alapján saját szerkesztés 


\section{3. ábra: A magyar gímszarvas borjú értékesítésének alakulása (2006-2016)}

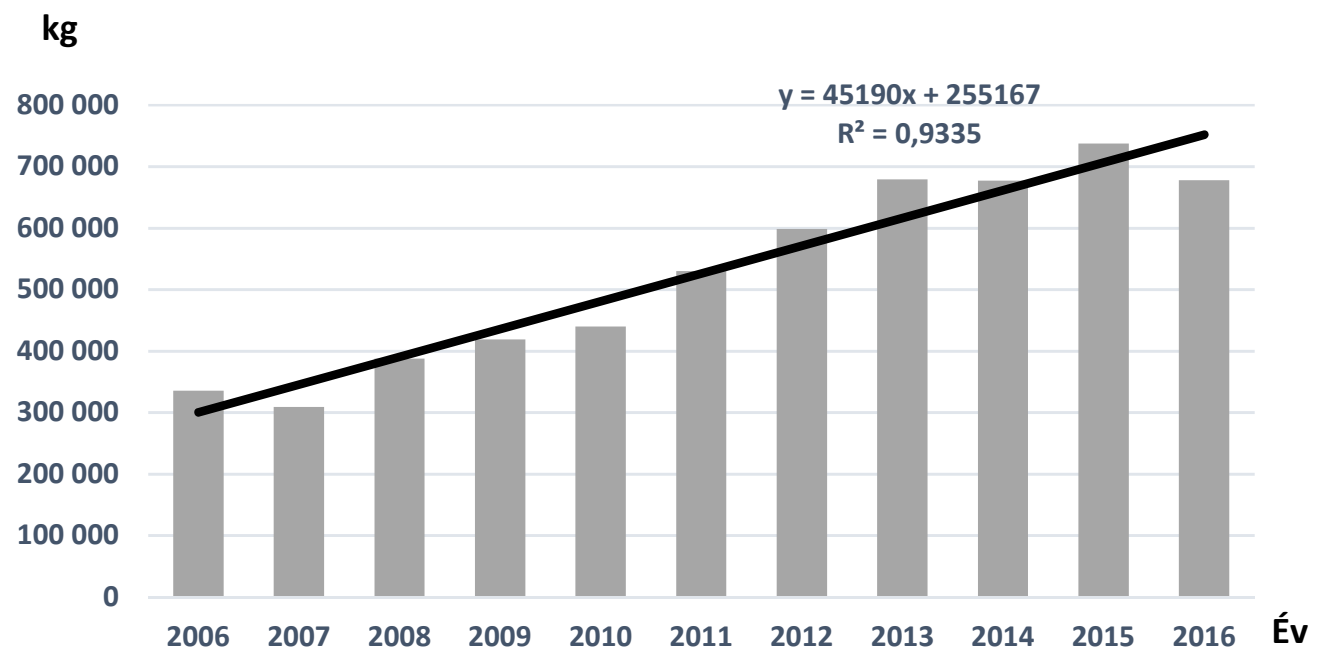

Forrás: OVA adatok alapján saját szerkesztés

A dámszarvas esetében a bika-, a tehén- és a borjúhús értékesítése képezte a vizsgálat tárgyát. Ezen lőtt nagyvadnál is növekedés volt tapasztalható az értékesítés területén. A vizsgált időszakban a bikahús iránti fizetőképes kereslet növekedett a legnagyobb mértékben, 2006-ról 2016-ra 94,5\%-kal (4. ábra). Nem sokkal maradt el az értékesítés aránya a tehénhús esetében sem. E téren a bázis évről a tárgyévre 84,3\%-os növekedés jelentkezett (5. ábra). Szintén jelentős mértékben bővült a borjúhús iránti fizetőképes kereslet is. Megállapítható, hogy 2006-ról 2016-ra 75,5\%-kal növekedett a borjúhús értékesítése (6. ábra).

Az őz esetében a bak-, a suta- és a gida húsának értékesítését vettük górcső alá. A rendelkezésre álló adatókból készült számítások alapján megállapítható, hogy mindhárom esetben növekedés volt jellemző az értékesítés területén. Az őzbak húsának értékesítése a tárgyévre a bázisévhez képest 35,5\%-os növekedést produkált (7. ábra). Az őzsuta esetében jelentősebb volt a növekedés 2006-ról 2016-ra. Az őzsuta húsának értékesítése 76,3\%-kal növekedett a bázisévről a tárgyévre (8. ábra). $\mathrm{Az}$ őzgida húsa iránti fizetőképes kereslet is növekedést mutatott a vizsgált időszakban. Az őzgida húsának értékesítése 67,4\%-kal növekedett 2006-ról 2016-ra (9. ábra). 


\section{4. ábra: A magyar dámszarvas bika értékesítésének alakulása (2006-2016)}

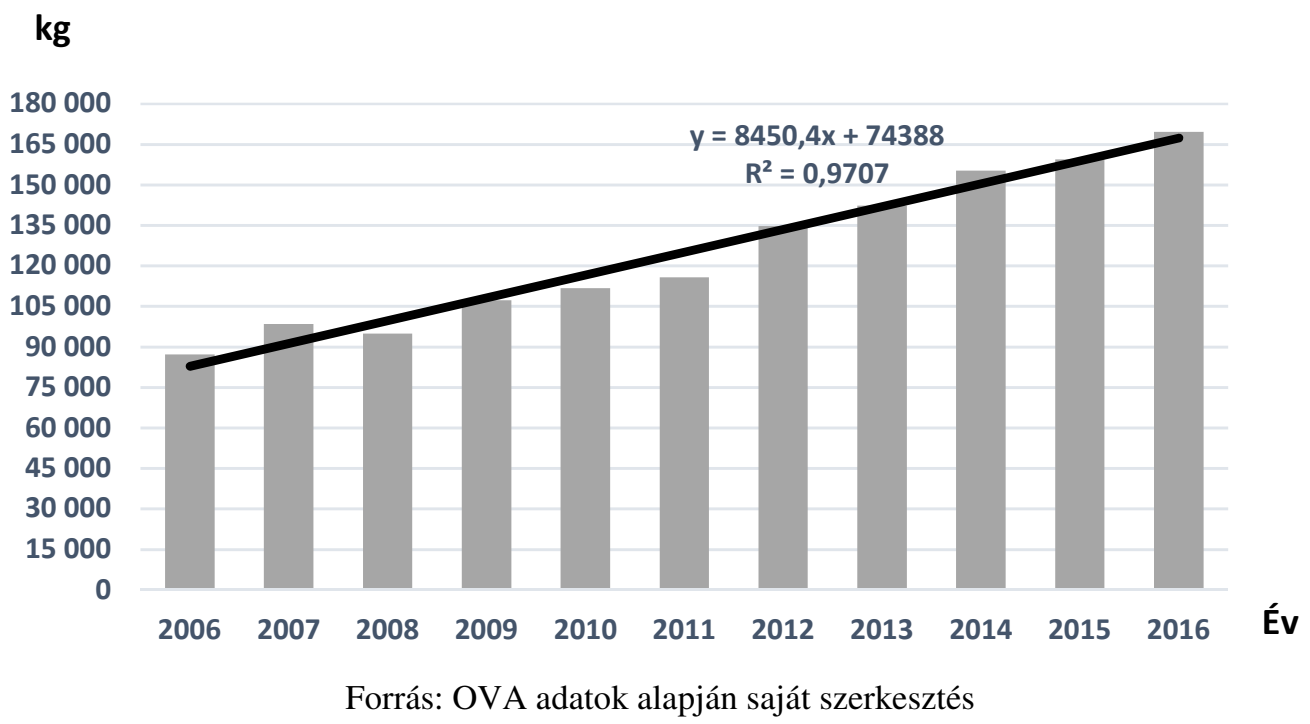

5. ábra: A magyar dámszarvas tehén értékesítésének alakulása (2006-2016)

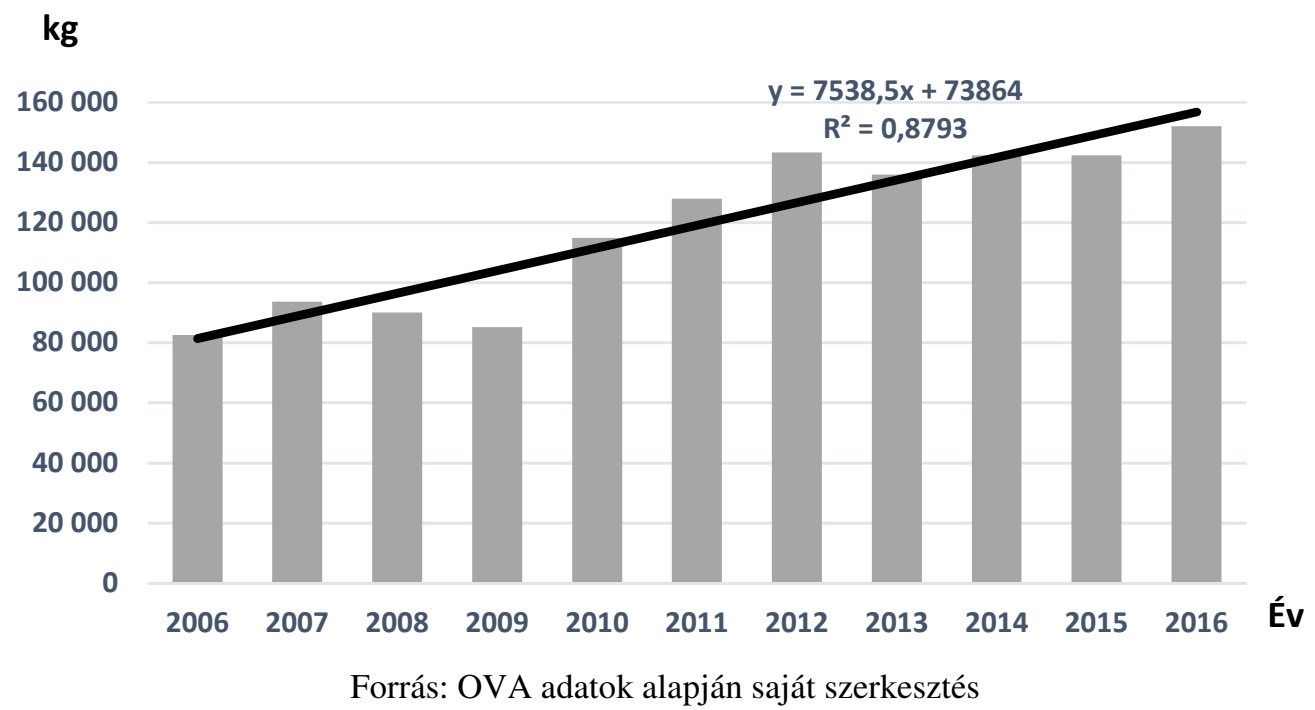


6. ábra: A magyar dámszarvas borjú értékesítésének alakulása (2006-2016)

$$
\text { kg }
$$

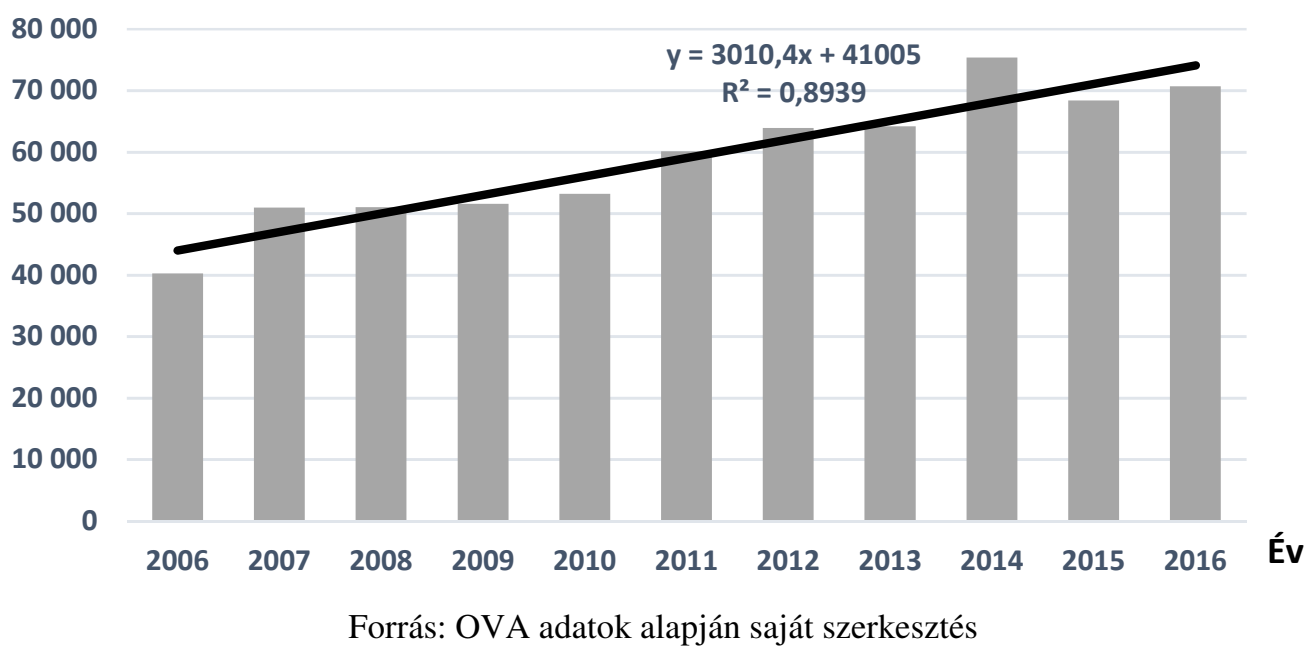

7. ábra: A magyar őzbak értékesítésének alakulása (2006-2016)

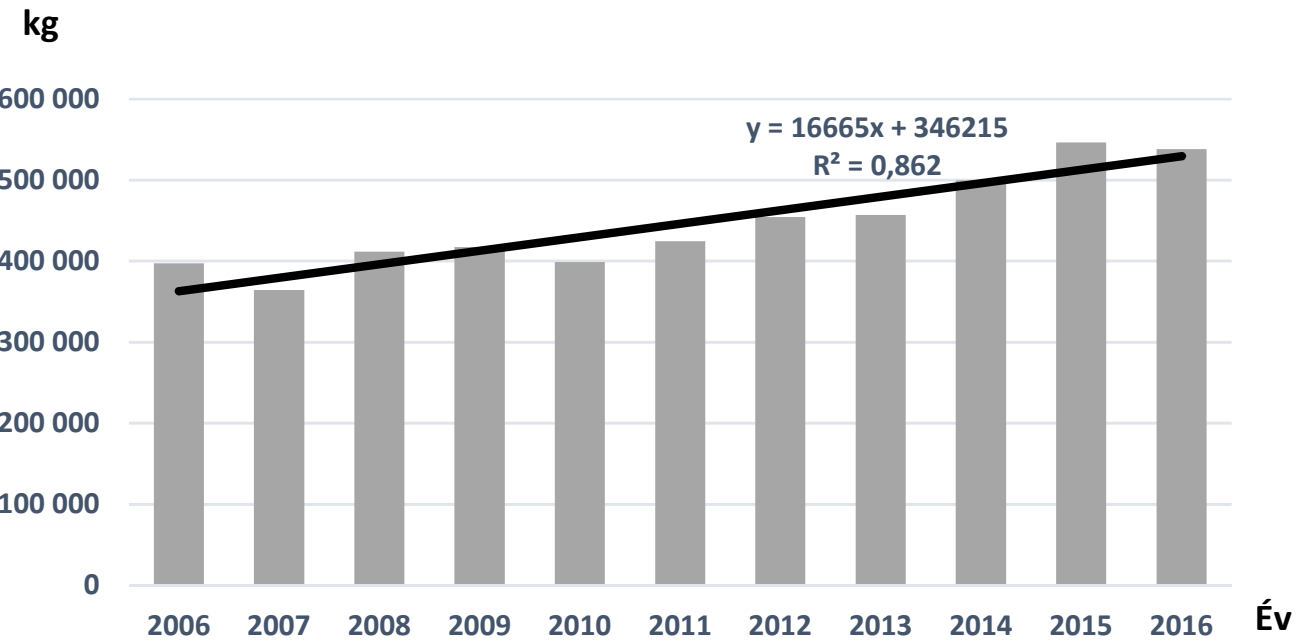

Forrás: OVA adatok alapján saját szerkesztés 


\section{8. ábra: A magyar ôzsuta értékesítésének alakulása (2006-2016)}

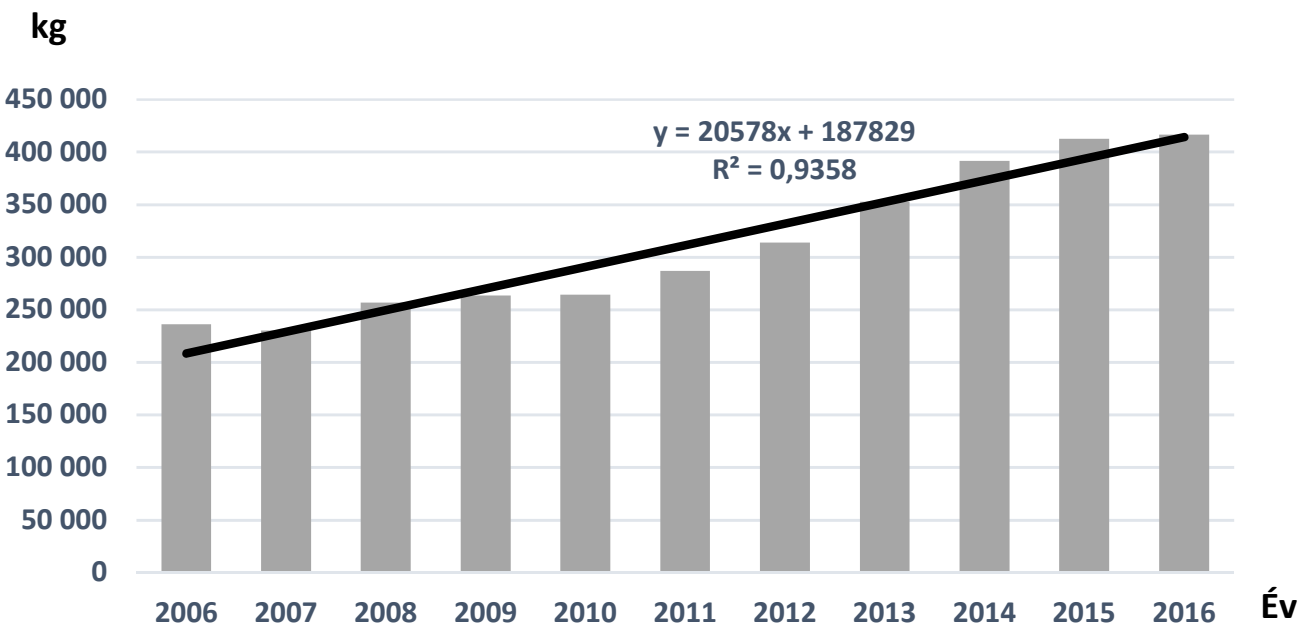

Forrás: OVA adatok alapján saját szerkesztés

\section{9. ábra: A magyar özgida értékesítésének alakulása (2006-2016)}

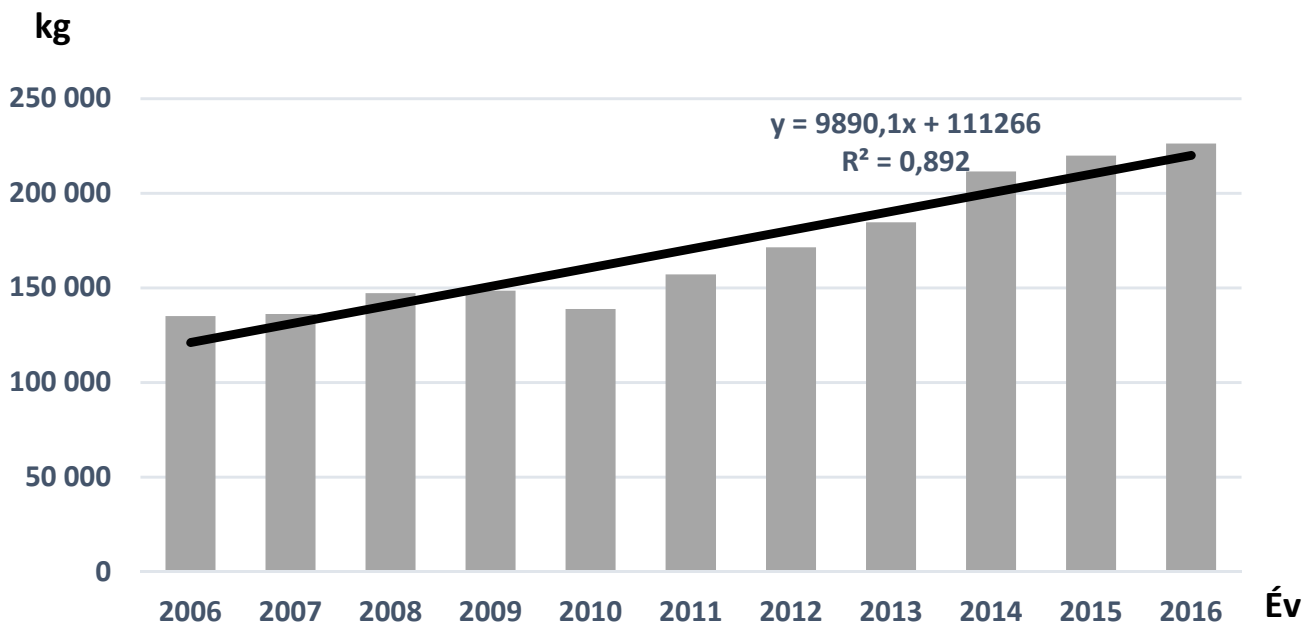

Forrás: OVA adatok alapján saját szerkesztés

A muflon húsának fogyasztása szerényebb keretek között zajlik, de megállapítható, hogy ezen lött nagyvad esetében is növekvő tendencia érvényesül az értékesítés területén. A muflon kos húsának értékesítése 39,1\%-kal növekedett 2006ról 2016-ra (10. ábra). A növekedés azonban nem volt töretlen, de ennek ellenére tendenciája azonban növekvő. A muflon jerke húsának értékesítését illetően elmondható, hogy értékesítése nagyjából a muflon kos húsának értékesítéséhez hasonló. A muflon jerke húsának értékesítése a tárgyévre a bázisévhez képest 39,2\%kal növekedett (11. ábra). A muflon bárány értékesítési volumenen jóval a kos és a jerke értékesítési volumenen alatt marad. Ennek ellenére az iránta való fizetőképes kereslet 2016-ra, 2006-hoz képest 92,4\%-kal növekedett (12. ábra). 
A lőtt nagyvadak közül a legjobban keresett a vaddisznó húsa. Értékesítési volumene olykor többszöröse a többi lőtt nagyvad értékesítési volumenének. Csúcspontját 2012-ben érte el, amikor közel 5,7 millió kg vaddisznó húst sikerült értékesíteni. A vaddisznó kan húsának értékesítése kisebb megtorpanással, de növekvő tendenciát mutat. A megtorpanást a piaci túlkínálat idézte elő. Ennek ellenére a bázis évhez képest a tárgyévre $62,7 \%$-kal növekedett az értékesítés ezen a téren (13. ábra). Az elmúlt évek adatai azt igazolják, hogy a vaddisznó kan húsának értékesítési piaca ismét növekedésnek indult a megtorpanást követően. Ez a túlkínálat csökkenésének és a piaci egyensúly megteremtésének köszönhető. A vaddisznó koca húsának értékesítési tendenciája nagymértékben hasonlít a vaddisznókan húsának értékesítéséhez. Itt is megállapítható az értékesítésben a megtorpanás. Ennek ellenére a vaddisznó koca húsának értékesítésében 90,4\%-os növekedés volt tapasztalható 2006-ról 2016-ra (14. ábra). A vaddisznó süldő húsának értékesítése szintén 2012-ben érte el csúcspontját a vizsgált időszakban. 2013-ban kisebb visszaesés volt tapasztalható, de ezt követően ismét megélénkült az iránta való fizetőképes kereslet, és növekedés következett be az értékesítésében. Az értékesítés ezen a téren a bázisévről a tárgyévre több mint kétszeresére növekedett (15. ábra). A vaddisznó malac húsának értékesítésében szintén növekedés volt tapasztalható. 2006-ról 2016-ra több mint 2,5-szeresére növekedett az értékesített hús volumene (16. ábra)

\section{0. ábra: A magyar muflon kos értékesítésének alakulása (2006-2016)}

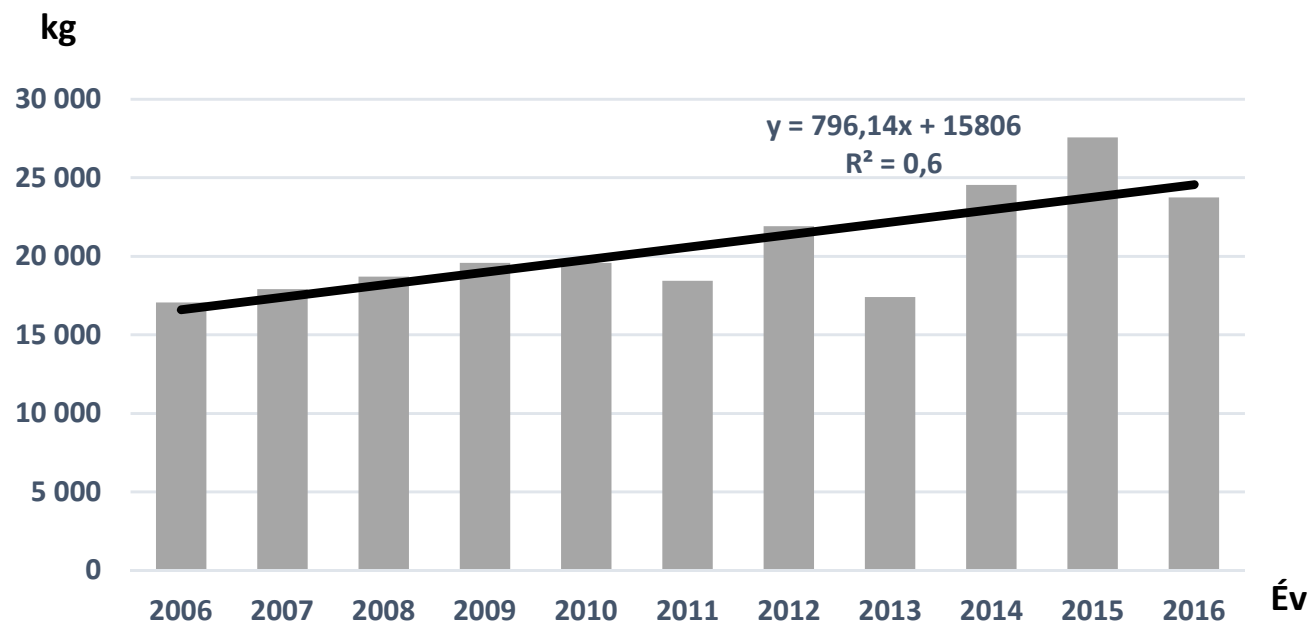

Forrás: OVA adatok alapján saját szerkesztés 
11. ábra: A magyar muflon jerke értékesítésének alakulása (2006-2016)

$$
\text { kg }
$$

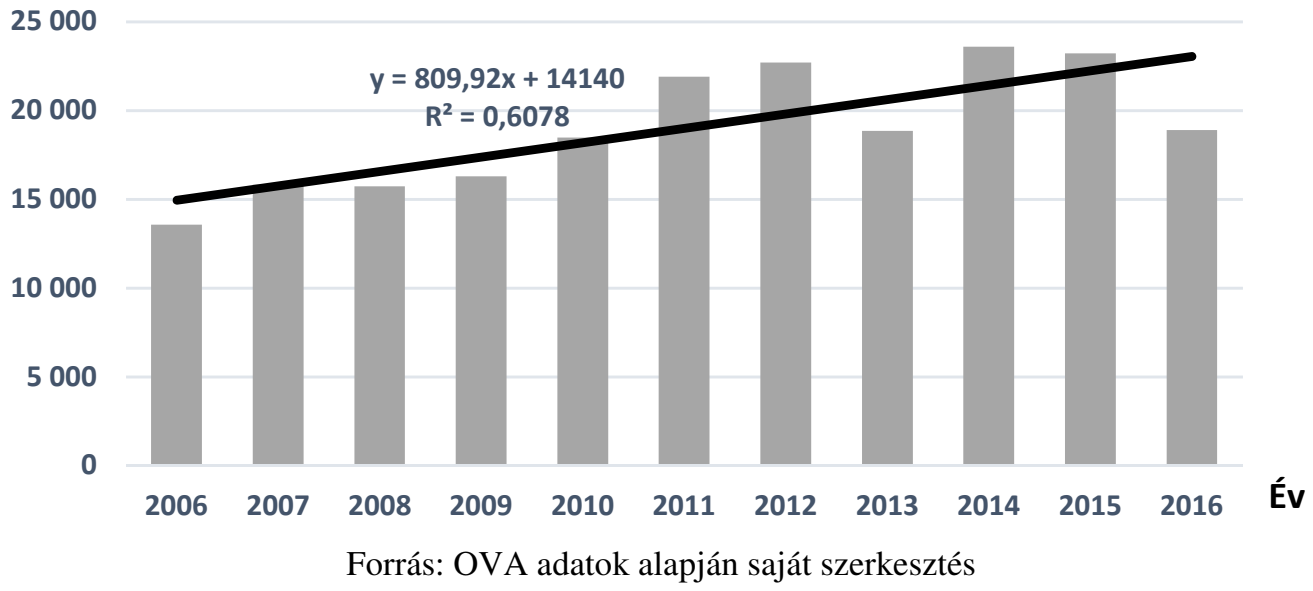

12. ábra: A magyar muflon bárány értékesítésének alakulása (2006-2016)

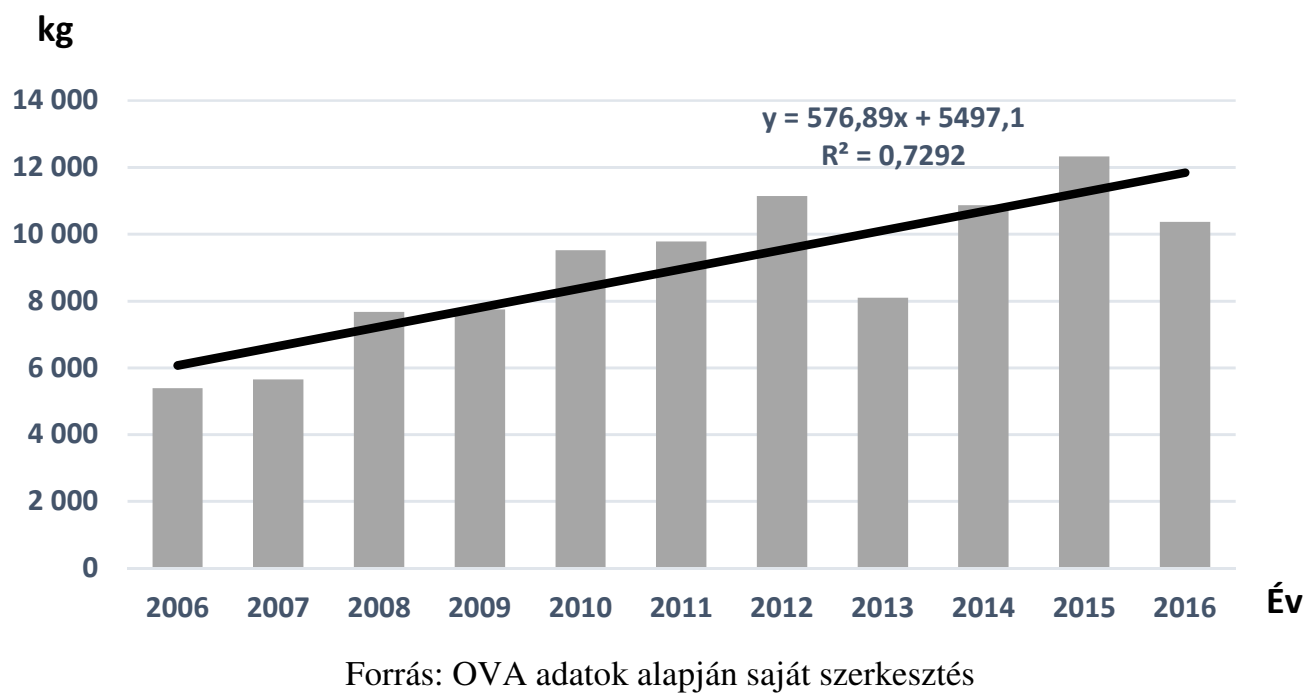




\section{3. ábra: A magyar vaddisznó kan értékesítésének alakulása (2006-2016)}

\section{kg}

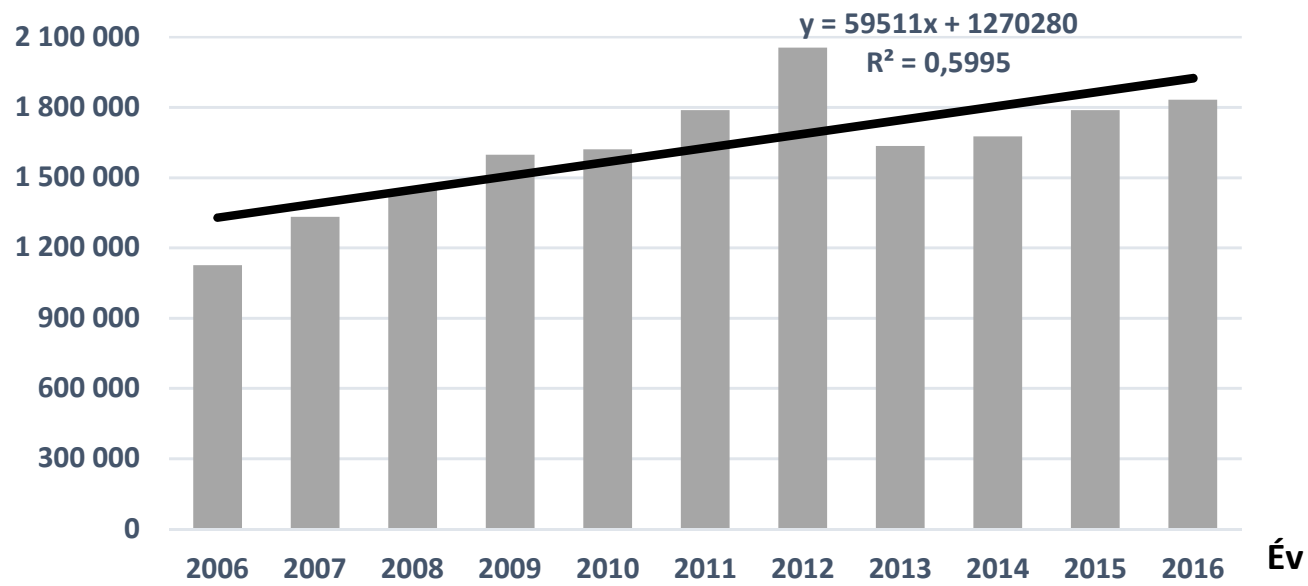

Forrás: OVA adatok alapján saját szerkesztés

\section{4. ábra: A magyar vaddisznó koca értékesítésének alakulása (2006-2016)}

$$
\text { kg }
$$

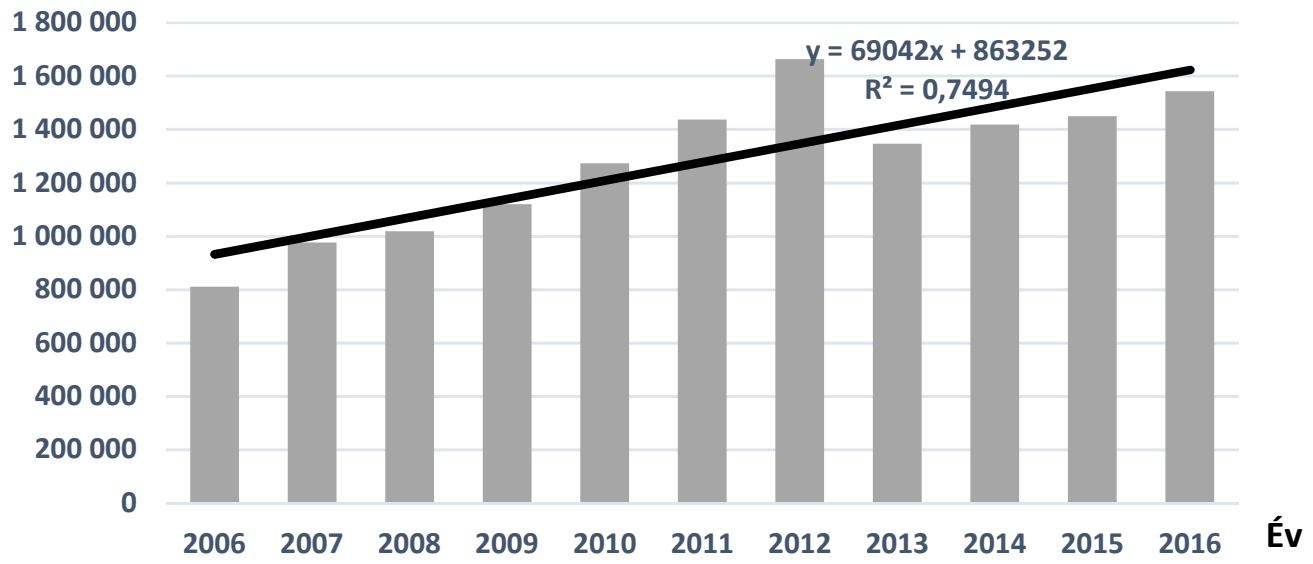

Forrás: OVA adatok alapján saját szerkesztés 
15. ábra: A magyar vaddisznó süldő értékesítésének alakulása (2006-2016)

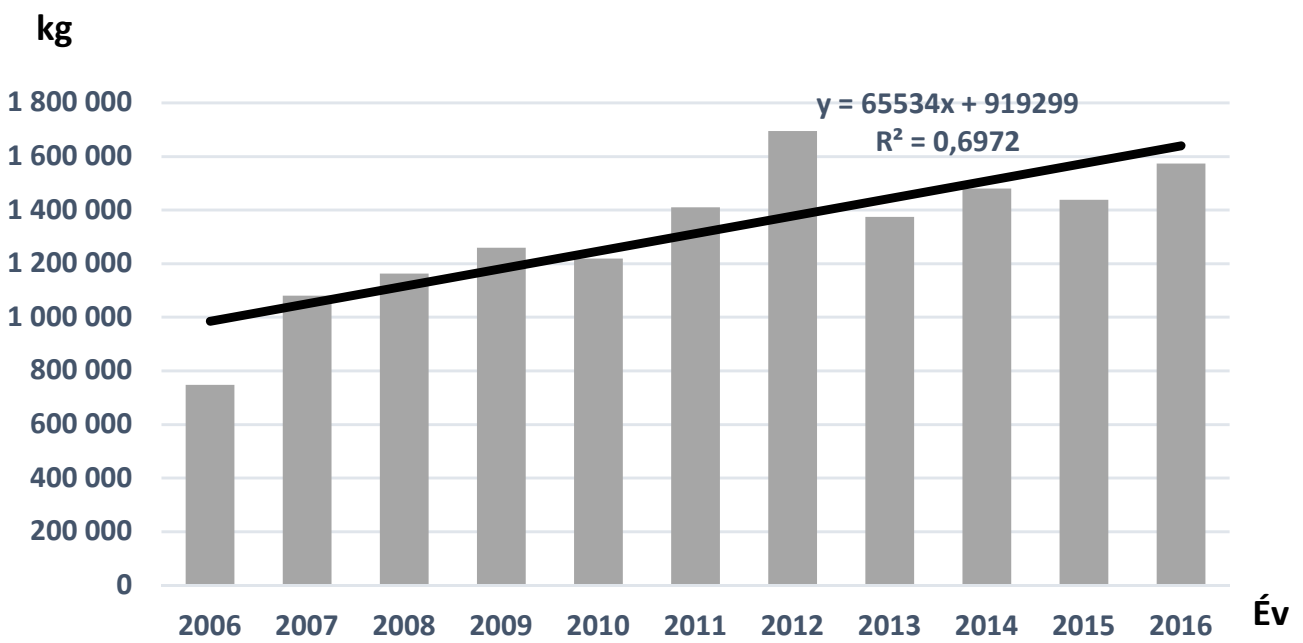

Forrás: OVA adatok alapján saját szerkesztés

16. ábra: A magyar vaddisznó malac értékesítésének alakulása (2006-2016)

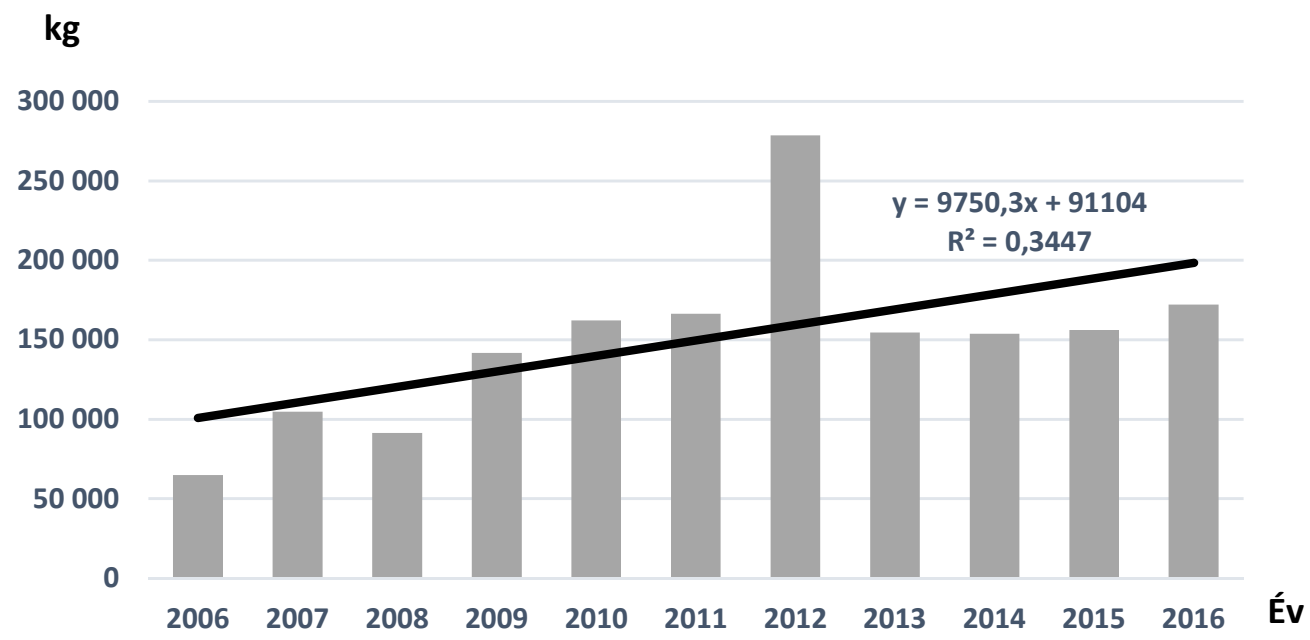

Forrás: OVA adatok alapján saját szerkesztés

A magyar lőtt nagyvadak értékesítésének alakulásában az export játssza a meghatározó szerepet. Az értékesített magyar vadhús iránt föleg európai piacokon mutatkozik jelentősebb fizetőképes kereslet. Az európai országok közül Németország, Ausztria, Csehország, Hollandia és Olaszország emelhető ki elsősorban ezen a téren.

A magasabb életszínvonallal rendelkező országokban az egy före jutó jövedelem is nagyobb. Ez jelentős hatással van a magasabb árfekvésủ termékek megvásárlására. Olyan országokban, ahol az átlagemberek magasabb összeget is hajlandók kifizetni az élelmiszerekért, nem okoz problémát a prémium minőségü magyar vadhúst értékesíteni. Jelenleg Nyugat-Európában a magyar értékesítés összességében a teljes 
piacot tekintve 5\% körül van. Ennek az aránynak a növelése lenne a legfontosabb gazdasági cél. Ehhez azonban fel kell venni a versenyt a versenytársakkal. Az Amerikai Egyesült Államokban, Ausztráliába, illetve Új-Zélandon napjainkban üzemszerüen tenyésztik a vadat, főként szarvast. Ausztráliában az elvadult házi sertések feldolgozása a jellemző. Olykor ciklikusan érkeznek Európába 24 tonnás konténerek, melyek telítik a vadhúspiacot. A nagy mennyiség magával vonzza a raktárkészletek telítődését, amelynek eredményeképpen túlkínálat alakulhat ki a lőtt nagyvadak értékesítését illetően. Az Európába beáramló nagymennyiségü vadhús az értékesítési árak zuhanásához vezethet. A tengerentúli szállítmányok érkezése nem látható előre, valamint a konkurencia árukészletei sem nyilvánosak, így elmondható, hogy a piac nem kiszámítható. A keresleti oldal folyamatosan változik, bizonyos termékek iránti érdeklődés sem állandó. A hazai értékesítők helyzetét akár olyan tényező is befolyásolhatja, hogy a német, osztrák, lengyel konkurensek készletei milyen ütemben telítődnek. Amennyiben valamely termékből jelentős többlet keletkezik, a gyors hasznosítás érdekében csökkentik az árakat. A kisebb piaci szereplőknek, amennyiben hatékonyan szeretnék értékesíteni termékeiket, követniük kell a nyugat-európai ártendenciákat. Ha a nagy, tengerentúli konkurensek (Amerikai Egyesült Államok, Új-Zéland, Ausztrália) példáját vesszük alapul, elgondolkodtató lehetőség a farmokon való nagyüzemi vadnevelés, majd az erre szakosodott vágóhíd létrehozása. A vágóhídi feldolgozás nem csak a volument növelné, hanem a piac határait is megnyitná, hiszen az Ázsiába (föként Japán) történő exportálás szigorú állategészségügyi követelményei sem okoznának gondot egy minden elöírásnak megfelelő, modern vágóhíd számára. Ennél a gondolatnál azonban felmerül, hogy amennyiben intenzív tartású, nagyüzemi farmok létesülnének hazánkban, a vadhús mennyire tudná megőrizni egyediségét, kiváló beltartalmi értékeit. Reálisan tekintve a tartástechnológiára, a farmszerü tenyésztés esetén a vad nem minden esetben tud hozzájutni azokhoz a táplálékforrásokhoz, amelyek a természetben rendelkezésére állnak. Az a gazdálkodó, aki ezeket a feltételeket szeretné biztosítani, rengeteg többletköltséggel kell, hogy számoljon. Ebben a jövőképben nem a prémium minőség, hanem a nagy mennyiség tudna kiemelkedő profitot termelni.

\section{Következtetések és javaslatok}

Az elmúlt évek során a tartósan import vadhúsra szoruló nyugat-európai vadhús piacon a magyar vadhúsok kiváló minőségüknek köszönhetően igen keresettek. Ez a piac a teljes magyar vadhús mennyiségét képes felvenni, sőt egyes becslések alapján ennek akár többszörösét is. Ugyanakkor számolni kell a tengerentúli versenytársakkal. A legnagyobb konkurenciát az értékesítés területén az állatfarmokon nevelt, nem vadon élö, az európai piacokon rendszeresen megjelenő, a legtöbb esetben alacsonyabb árfekvésủ amerikai, új-zélandi és ausztrál tenyésztett vad húsa jelenti. Ez elsősorban a szarvas- és a vaddisznóhús értékesítésénél okozhat problémákat. A tengerentúlról elsősorban Nyugat-Európába érkező vadhús kiszámíthatatlan mennyisége, olykor jelentős dömpingje, jelentős mértékben negatív 
irányba befolyásolhatja az árakat, amelynek kivédésére sajnos egyelőre nincs lehetöség.

A magyar vadhús világhírü minősége nem vitatott. A „prémium kategóriába” való tartozást erősíteni kell értékének megörzésével. Mivel a közeljövőben nincs lehetőség a nagyipari előállításra, Európa „elárasztására”, így mindenképpen a kiváló tulajdonságok kiemelésében rejlik az export adta növekedési lehetőség. Ennek több módja is lehet, melyek a következőkben foglalható össze:

- új, termékspecifikációk létrehozása,

- feldolgozott termékek (kolbász, szalámi, füstölt áru) népszerüsítése,

- hungarikummá nyilvánítás.

Az új termékspecifikációk kialakítása során figyelembe kell venni a piaci igényeket. Jelenleg a szarvashús, második helyen pedig a vaddisznóhús a legkelendőbb. A termékek szempontjából a szarvasgerinc és comb, vaddisznóból pedig a lapocka a legnépszerübb. A vizsgálatok alapján azonban elmondható, hogy a piac itt is olykor hektikusságot mutat. Sem az szezonális, sem ciklikus változást vagy mintát nem mutat, így szinte lehetetlennek tünő feladat előre megjósolni az elkövetkezendő időszak keresleti igényeit. A folyamatos piackutatás, a lakosság körében elvégzett felmérések információforrásként szolgálhatnak a hazai cégek számára a termékpaletta bővítésében, kialakításában. A vásárlók pontos igényei az alábbiak szerint lenne célszerü felmérni:

- faj- a legnépszerübb fajok a vásárlók körében,

- fötermék- mely testrészek a vásárlók számára a legértékesebbek, milyen formában egészben, vagy esetleg szeletelt áruként,

- csomagolás - vákuum, védőgáz, egyenként fóliában való csomagolás,

- kiszerelés- tálcás, elővágott $(500 \mathrm{gr}, 1 \mathrm{~kg}$, stb.),

- felhasználási terület - sütés, fözés, grill sütés - ettől függően akár egy elöpácolt termék is kelendő lehet,

- késztermékek (szalámi, kolbász, füstöl áru) iránti kereslet.

- $\quad$ Az igényektől függően az előállító el tudja dönteni, hogy van-e kapacitása a kereslet által meghatározott termékek előállítására. Ezek természetesen mind plusz költségekkel járnak, melyek az alábbiak szerint csoportosíthatók:

- gépek korszerüsítése, minőségi cseréje által létrejövő kiadás (csomagolás, darabolás, szeletelés, anyagmozgatás, súlyellenőrzés),

- új/meglévő munkaerő által létrejövő kiadás (alkalmazottak létszámának növelése, túlórák),

- $\quad$ új anyagok beszerzése által létrejövő kiadás (csomagolóanyag, gyártáshoz felhasznált anyagok, pl.: füszerek),

- engedélyek beszerzése (pl.: késztermék előállításhoz).

A cégeknek mérlegelniük kell, hogy a fejlesztésekre szánt befektetések hosszútávon jövedelmezővé válnának-e számukra.

Néhány cég foglalkozik késztermék elöállítással, valamint hazánkban is kezd egyre populárisabbá válni a vadhúsból készített áru (pl. szalámi, kolbász, stb.). Fontosnak tartjuk e termékek népszerüsítését külföldön, hiszen a jó minőség mellett 
egy rendkívül jól eladható áruról van szó. Bár az előállítás magasabb költségekkel és nagyobb ráfordítással jár, a kereslet is nagyobb lehet. Véleményünk szerint a fogyasztók egy része szívesebben vásárol olyan terméket, amelyet gyorsan el tud készíteni, egyszerủ eljárással fogyaszthatóvá válik. A késztermékek emellett a boltok polcain könnyen elhelyezhetők. Megfelelő csomagolással kitünhet a többi termék közül. Ehhez persze szükség van a kiváló minőség előállítására, hiszen a szép csomagolás még nem jelenti a termék sikerét a piacon. A kellő gondossággal, magyar vadhúsból, hazánkban előállított késztermékeknek jelentős sikere lehet külföldön. Ebből kifolyólag mind az alapanyag, mind a késztermék érdemessé válhat arra, hogy felkerüljön a hungarikumok listájára.

A magyarországi vadhús piac helyzetének és piaci lehetőségeinek megítélését segíti az elkészített SWOT analízis (1. táblázat). Ennek segítségével meghatározásra kerültek azok a belső és külső tényezők, amelyek a vadhús piacra és ezen keresztül a vadhúsértékesítésre pozitív vagy negatív hatással lehetnek.

1. táblázat: A magyar vadhús piac SWOT analízise

\begin{tabular}{|c|c|}
\hline \multicolumn{2}{|c|}{ BELSŐ TÉNYEZŐK } \\
\hline ERÖSSÉGEK (S) & GYENGESÉGEK (W) \\
\hline széleskörü termelési vertikum & $\begin{array}{l}\text { egyes területeken technológiai } \\
\text { elmaradottság }\end{array}$ \\
\hline előnyős termékszerkezet & fellépő forráshiány \\
\hline fejlett müszaki adottságok & kapacitások kihasználatlansága \\
\hline magas szakmai tapasztalat & magas szállítási költségek \\
\hline kiépített, jól működő felvásárlói hálózat & marketing tevékenység \\
\hline magas élelmiszerbiztonság (ISO, HACCP) & \\
\hline \multicolumn{2}{|c|}{ KÜLSŐ TÉNYEZŐK } \\
\hline LEHETŐSÉGEK (O) & VESZÉLYEK (T) \\
\hline kedvező földrajzi helyzet & erös piaci verseny \\
\hline a vadhús fogyasztás iránti növekvő kereslet & túlkínálat \\
\hline folyamatos fejlesztési pályázatok & erösen ingadozó fogyasztópiac \\
\hline $\begin{array}{l}\text { marketing lehetőségek a hazai és a külföldi } \\
\text { piacon }\end{array}$ & felhalmozódó készletek \\
\hline $\begin{array}{c}\text { kihasználatlan piaci rések a hazai és a } \\
\text { külföldi piacon }\end{array}$ & tenyésztett olcsóbb vadhús \\
\hline
\end{tabular}

Forrás: A szerzők saját szerkesztése.

Az elkövetkező időszakban is nagy hangsúlyt kell fektetni a vadgazdálkodásra és ezen keresztül a vadhús értékesítésére belföldön és külföldön egyaránt annak érdekében, hogy a vadgazdálkodás (vadhúsértékesítés) növekvő szerepet tölthessen be nemzetgazdaságunk- és a vidék fejlődésében, ezáltal tovagyürüző multiplikatív hatást kifejtve. 


\section{Irodalomjegyzék}

Abonyiné Palotás J., Komarek L. (2004): Élelmiszerfogyasztásunk területi differenciáltsága: Regional diversification of food consumption in Hungary. In: Hodúr C., Kovács E., Véha A., Szücs E. (szerk.): A VI. Nemzetközi Élelmiszertudományi Konferencia elöadásainak és posztereinek összefoglalói: 6th International Conference on Food Science. 285 p. Konferencia helye, ideje: Szeged, Magyarország, 2004.05.20-2004.05.21. Szeged: Szegedi Tudományegyetem Élelmiszeripari Főiskolai Kar, 2004. 208-209.

Balsay M. (2013): A vadhúsfeldolgozás Magyarországon. In. Nagy E., Bíró G. (szerk.): A vadgazdálkodás idöszerü kérdései. A hazai vadhús hasznosítás helyzete és távlatai konferencia. Országos Magyar Vadászkamara, Budapest. 21-26.

Berger A., Csányi S. (2015): „Számoljunk utána!” Magyar Vadászlap, 24 (6): 8-11.

Bíró G. (2002): Élelmiszer-higiénia. Agroinform Kiadó Kft., Budapest.

Gombos Z., Herényi B. (2012): Vadhúsvizsgálat és minősítés. Országos Magyar Vadászkamara, Budapest.

Földvári A. (2013): „Elvadult” húsárak. Magyar Vadászlap, 22 (5): 296-297.

Földvári A. (2014): Vadhúspiac nyílik. Magyar Vadászlap, 23 (2): 99.

Hajas P. P. (2013): A közvetlen vadhús értékesítés jól müködő európai példái. $<$ http://omvkpest.hu/ordered/9464/pic/mappa2/hajas.pdf> (2018.07.15.)

Horváth J., Komarek L. (2016): A világ mezőgazdaságának fejlödési tendenciái, Szegedi Tudományegyetem Mezőgazdasági Kar, Hódmezővásárhely.

Komarek L. (2004): Élelmiszerfogyasztásunk alakulásának főbb vonásai. In: Hodúr C., Kovács E., Véha A., Szűcs E. (szerk.): A VI. Nemzetközi Élelmiszertudományi Konferencia elöadásainak és posztereinek összefoglalói: 6th International Conference on Food Science. 285 p. Konferencia helye, ideje: Szeged, Magyarország, 2004.05.20-2004.05.21. Szeged: Szegedi Tudományegyetem Élelmiszeripari Főiskolai Kar, 2004. 45-46.

Komarek L. (2005): Élelmiszerfogyasztásunk időbeni alakulása. A földrajz tanítása. Módszertani folyóirat. 13 (4): 25-30.

Komarek L. (2008): A Dél-Alföld agrárszerkezetének sajátosságai. Csongrád Megyei Agrár Információs Szolgáltató és Oktatásszervező Kht, Szeged.

Kőhalmi T., Márkus L. (1996): Vadászati ökonómia. Jegyzet. Soproni Egyetem, Sopron. $<$ http://www.nyme.hu/uploads/media/jegyzet_vadgazd_okon.pdf> (2018.07.15.)

Laczay P. (2008): Élelmiszer-higiénia Élelmiszerlánc-biztonság. Mezőgazda Kiadó Kft., Budapest.

Pechtol J. (szerk.) (2016): Vadászévkönyv 2016. Országos Magyar Vadászkamara, Budapest.

Süli-Zakar I., Komarek L. (2012): A Kárpát-medence élelmiszer-gazdasága. In: Dövényi Z. (szerk.): A Kárpát-medence földrajza. Akadémiai Kiadó, Budapest. 562-602. 